\title{
Old laws for new risks at sea: mineral resources, climate change, sea lanes, and cables
}

\author{
Uwe K. Jenisch
}

Received: 2 June 2011 / Accepted: 6 January 2012 /Published online: 31 January 2012

(C) World Maritime University 2012

\begin{abstract}
Maritime security in a broad sense means more than piracy and terrorism. This paper concentrates on the risk potential of current and future resource-related activities on the seabed. The seabed mining of hard mineral resources - in addition to hydrocarbons - leads to new controversial maritime boundary claims of states in their effort to expand national access rights to raw materials. Outer continental shelf claims in the Arctic Ocean are today's test bench for law of the sea conflicts. Fiber-optic cables running through regional seas, straits, and land bridges may become another risky issue, while the pattern of maritime transport routes is moving from Northern to Southern waters. Under a medium-term perspective, the sea level rise will endanger ports and coasts. Borderlines of maritime zones will move and thus generate more injustice and conflicts among states. The tools to solve borderline conflicts and options for dispute settlement are available in UNCLOS. Some other legal gaps are covered by the 2005 SUA Convention and by bilateral agreements, while resolutions by the UN Security Council begin to broaden rights of intervention and interdiction. The need for new laws remains.
\end{abstract}

Keywords Seabed resources and excessive claims $\cdot$ Natural disasters and climate change · Sea lanes and cables · UNCLOS · SUA Convention $2005 \cdot$ UN Security Council as a legislator

\section{Introduction}

Over the past years, we have witnessed that maritime violence, terrorism, and piracy are continuing to spread while the international legal system of interference rights and counter measures remains full of gaps in addressing these issues. In other words, the inadequacies of the legal system are part of the problem of security at sea.

U. K. Jenisch $(\bowtie)$

Walther-Schuecking Institute of International Law, University of Kiel, Kiel, Germany

e-mail: uwe.jenisch@t-online.de 
Piracy, terrorism, and the wave of political transitions in the Middle East and in Northeastern Africa dominate the headlines and plague the maritime transport sector which truly is the backbone of globalization. In fact, maritime transport represents the first and foremost globalized sector of the world economy. At the same time, there are other disturbing events in the larger marine environment that threaten society in different ways. Major technological disasters such as the 2010 Deepwater Horizon oil spill in the Gulf of Mexico or the nuclear catastrophe in Japan caused by the 2011 earthquake and ensuing tsunami are drawing public attention to further forms of environmental risk. Other critical developments such as rising sea levels attributable to climate change are highly certain to occur although uncertainty remains as to their extent. Over the remaining 89 years of this century, the global average sea level rise could range between 0.4 and $2 \mathrm{~m}$ with a most likely value of $0.8 \mathrm{~m}$. ${ }^{1}$ Moreover, the race for the last frontier of seabed resources in the deeper ocean has begun.

This paper will concentrate on international legal-political aspects of some of the "new" or "unconventional" maritime risks such as:

- Risks arising due to seabed resources including controversial (or excessive) maritime boundary claims.

- Natural disasters and climate change.

- Security of communication-sea lanes and cables.

Maritime security has many aspects, not to forget piracy and terror which are at the center of deliberations and resolutions of the UN Security Council and thus may serve as a starting point for new law as is shown in Section 5. In any case, governments, police forces, coast guards, and navies are well advised to understand security in a broader sense while their "coast-guarding" functions grow in littoral waters and beyond.

\section{Risks over marine mineral resources}

The world economy, still suffering from the financial crisis, is currently experiencing increasing commodity prices. Industrial associations and governments are monitoring patterns of supply and demand, not only for standard minerals like iron, but also for high-value metals (e.g., nickel, copper, titanium, gold) and rare earth elements (REE) like yttrium, indium, gallium, neodymium, and germanium (Kato et al. 2011) which are important for semi-conductors, photovoltaics, lasers, liquid crystal displays, fiberoptic cables, and other high-tech products used in both civilian and military applications. The demand for raw materials is expected to double in the next 25 years. The EU has identified a list of 14 out of 41 critical raw materials ${ }^{2}$ which are irreplaceable in key industries. The supply risk is due to the fact that a high share of production

\footnotetext{
${ }^{1}$ The Alfred Wegener Institute (Bremerhaven) predicts for the year 2050 an increase of $32 \mathrm{~cm}$ due to dramatically increased ice melting on the northern hemisphere; the actual (2010) increase worldwide is $1.3 \mathrm{~mm} /$ year. Some scientists argue for as much as $2 \mathrm{~m}$, while the Arctic Monitoring and Assessment Program predicts 0.9-1.6 m for the year 2100 (amap@amap.no).

${ }^{2}$ EU MEMO/10/263 of 17 June 2010; see also EU raw materials initiative COM (2008) 699 final of 04 November 2008
} 
comes from China, ${ }^{3}$ Russia, South Africa, the Democratic Republic of Congo, and Brazil. This production concentration cannot easily be substituted for or augmented by other sources. The political-economic stability of some of the producing states is questionable and, in the case of Congo, nearing collapse. The list of failing states will grow where humanitarian and environmental risks may get completely out of control. The risks for the supply chains are self-evident: old and newly industrialized states are competing over prices and access rights to the remaining raw materials, while the low-hanging fruits have been picked. As a consequence, interest in marine mineral resources is growing again. With only $29 \%$ of the world's surface being land and $71 \%$ being sea, there is every reason to believe that terrestrial minerals occur in deposits on and in the seabed, as well. The Pacific Ocean alone is larger than all land masses on earth.

Offshore oil and gas is a success story in itself. The sophisticated underwater technology of the offshore industry (floating production units, collectors, risers, pipe systems, and robots) can be adapted to ever-increasing water depths. The next step will be the mining of mineral ores and rare earth elements. At least five different types of marine mineral deposits can be distinguished:

- Manganese nodules of the deep seabed (3-6,000 m), mostly in international waters.

- Seafloor massive sulfide deposits containing $\mathrm{Cu}, \mathrm{Zn}, \mathrm{Pb}, \mathrm{Au}$, and $\mathrm{Ag}$ on submarine volcanic sites (est. 1,000 "black smokers"), at 100-4,000 m depth.

- Polymetallic (manganese) crusts (Mn, Co, Ni, Pt) on volcanic seamounts 8002,500 m.

- Hot brines (Cu, Au, Ag, and others) in the Red Sea trench (Atlantis II Deep).

- Diamonds and rare sands in shallow waters, at 90-140 m depth off the coast (Oranje River, Namibia).

\subsection{Minerals and the law of the sea}

Of course, minerals from the seabed cannot replace terrestrial mining. Instead, they can complement the supply and make industry more independent of critical suppliers to the extent that costs and technology allow it to do so. According to many experts, the break-even point is near, while the legal-political conditions are favorable. Beginning in this decade, we will see a new "rush and grab" of competing interests going deep sea and the big questions are:

- Who owns the minerals?

- Who has the right to access?

- Who is responsible for environmental protection?

The answer to these questions is enshrined in the 1982 UN Convention on the Law of the Sea (UNCLOS). ${ }^{4}$ Basically, there are two different approaches to seabed mining under the UNCLOS regime:

\footnotetext{
${ }^{3}$ E.g., $97 \%$ of current REE production and $48 \%$ of REE reserves are based in China.

${ }^{4}$ UNCLOS of 1982, in force since 1994 and binding upon 162 states parties (October 2011); articles quoted hereinafter without further details are those of UNCLOS.
} 


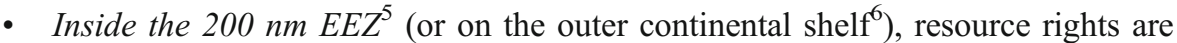
exclusively those of the coastal state. Exploitation is possible only with the consent of the mining authority of that State.

- In the international area outside the limits of national jurisdiction, called "The Area" under the regime of the International Seabed Authority, ISA, ${ }^{7}$ based in Kingston/Jamaica. Under the concept of the heritage of mankind, these resources are open to all states.

Like in the case of offshore oil and gas, it is logical to assume that the future extraction of minerals begins inside the EEZ of $200 \mathrm{~nm}$, where the coastal state has sovereign rights of exploring and exploiting, conserving and managing the natural resources, whether living or non-living, and jurisdiction over artificial islands, installations, and structures. In this case, the domestic legal system of the coastal state is applicable which means that mining law, tax law, licensing system, environmental law, etc. have to be observed. The mining company based in state A can mine in the EEZ of state B on the basis of a license, of a joint venture agreement, or any other bilateral arrangement.

Bilateralism is the model case. States with rich deposits in their EEZ - e.g., tiny island states like Fiji and states with long coastlines like Chile - find themselves in a good bargaining position — or may become the target of a big and powerful state in need of raw materials.

The following examples demonstrate that the race has begun. The Toronto-based Nautilus Minerals Inc. ${ }^{8}$ received its first production license for the Solwara 1 project from Papua New Guinea in January 2011 and has pending applications for the EEZ of Fiji and other places. Sydney-based Neptune Minerals is exploring the seabed off New Zealand. De Beers of South Africa, an offshore diamond miner, is adapting its technology for similar projects in the Coral Sea. ${ }^{9}$ The Dutch firm "OceanflORE" is elaborating a project study for the exploitation of phosphorites off the coast of New Zealand while the US Geological Service is working on an inventory of the seabed riches of Pacific territories and associated states in the area. A poor Pacific island may become a bonanza. A tiny island or a reef and a rock may become the trigger of a maritime clash, ending up in an incident or a military occupation.

\subsection{Mining on the seabed in contested zones}

Thus, the significance of marine space under national jurisdiction is increased once again as hard minerals are entering the scenes. The competition for natural resources poses considerable conflict potential. It can destabilize already fragile states and regions. It comes as no surprise that states will try to nationalize as much sea space as they can. For this purpose, they will make maximum use of the UNCLOS toolbox consisting of expanded base lines, territorial sea limits, contiguous zones, EEZs, and

\footnotetext{
${ }^{5}$ See UNCLOS Part V (arts. 55-75).

${ }^{6}$ See UNCLOS Part VI (arts. 76-85).

${ }^{7}$ See UNCLOS part XI (arts. 133-191).

${ }^{8}$ www.nautilusminerals.com

${ }^{9}$ Wall Street Journal of 6 November 2009.
} 
outer continental shelf zones. Conflicts over sea borders which calmed down in the past will boil up again.

The best collection of the maritime boundary practice of states is the six-volume publication International Maritime Boundaries (Colson and Smith 1993-2011) with some 240 boundary reports and maps including regional reports of sensible seas like the Mediterranean, Baltic, Red Sea/Persian Gulf, Caspian, Caribbean, and others. However, an estimated minimum of 100 maritime boundaries in the world are still disputed or otherwise unresolved. The typical ingredients of a maritime border conflict are territorial claims, resources, and sea lanes.

While some regional seas like the North Sea and Baltic Sea and the Caribbean are divided up by many long-standing maritime boundaries, others like the Mediterranean and the South China Sea are largely unregulated. For example, there are only two short median lines agreed upon between Cyprus/Egypt and Cyprus/Lebanon and some $70 \mathrm{~nm}$ of a southern border of Lebanon's EEZ with Israel. ${ }^{10}$ The rest of the south-eastern part of the Mediterranean is a bone of contention between Turkey, Syria, Cyprus, Lebanon, Egypt, Israel, and the future Palestinian state where gas fields (Leviathan, Gaza Marine) have been discovered and licenses have been issued. Israel has to protect its offshore platforms against Hisbolla attacks. ${ }^{11}$ Another salient problem is the delimitation of the maritime zones which could be attributed to Israel on the one hand or to the Gaza territory on the other. The conflict between Israel and its neighbors has a maritime dimension, largely underestimated for a long time. It came to the surface when Israel intercepted the "Gaza flottilla" of international peace activists in June 2010. On March 15, 2011, Israel's navy seized the containership Victoria $^{12}$ in international waters $300 \mathrm{~km}$ off the coast accusing the vessel of carrying radar-guided missiles of Iranian origin ${ }^{13}$ destined for the militia in Gaza. Israel presented three containers with arms in the port of Ashdod to foreign diplomats. Without going into the details, a legal basis for seizing arms (contraband) carried on neutral ships during a military conflict could be the right of sea blockade. ${ }^{14}$

Another current conflict refers to the uninhabited Senkaku (Diaoyu) Islands which are claimed by Japan, China, and Taiwan in an area where fishing grounds and gas field interests overlap. When the Japanese coast guard arrested a Chinese fishing boat in 2010, China used the incident to impose permanent export restrictions for trace metals. Needless to say that also the neighboring South China Sea is politically a hot spot (Crook 2010) where a military confrontation has been building up for years. It is a regional sea of 3 million $\mathrm{km}^{2}$, of which $80 \%$ is claimed by China.

The undelimited boundaries in the Red Sea represent another complex situation where Egypt, Sudan, Eritrea, and Saudi Arabia have failed to agree on a median line separating the Red Sea into a western and an eastern part. The situation is further blurred by excessive baselines, disputed islands, and contested land borders among the neighboring states of the region and by extremely rich mineral resources on the

\footnotetext{
${ }^{10}$ The Lebanese declaration (and map) of 2010 uses the wording "Southern Median Line (LebanonPalestine)," Law of the Sea Bulletin no. 73, New York, 2010, p. 39-42, and no. 74, 2010, p. 30.

11 Jerusalem Post of 10 August 2011.

12 German-owned vessel under the flag of Liberia, chartered by CMA/CGM on its way from Latakia (Syria) via Mersin (Turkey) to Egypt. See Frankfurter Allgemeine Zeitung of 17 March 2011.

${ }^{13}$ These arms were delivered to a Syrian port by Iranian warships a few days earlier; see Bruns (2011).

${ }^{14}$ San Remo Manual (1994), sect. 67a.
} 
seabed. In the 1960s, high concentrations of copper, lead, zinc, gold, and silver in the form of hot brines and metalliferous sediments have been discovered in the deep central parts of the Red Sea. Large amounts of material were recovered at that time. A pre-mining test was planned but never implemented. In 1974, Sudan and Saudi Arabia signed an agreement relating to a joint development zone ${ }^{15}$ under the management of the Saudi-Sudanese Red Sea Commission. The joint zone was established in the absence of a boundary agreement. It covers the whole seabed of the Red Sea between the two states which lies beyond the 1,000-m isobath (Prescott and Schofield 2005 , p. 487-489), but the northern and southern limits are not defined. All exploration work came to an end in the late 1970 s, and there is very little information about activities in the area since then.

In 2010, after consultations with Sudan, Saudi Arabia awarded an exclusive mining license for 30 years over the richest deposit known as the Atlantis II Deep. The Manafa Inc., an investment holding company active in the Middle East since 2003, could be among the first deep sea mining operators. It remains to be seen whether the old joint development agreement with Sudan can be reactivated if and when a lucrative mining operation starts. ${ }^{16}$ Optimists will hint at some UNCLOS rules such as art. 123 which encourages a close cooperation of states in semi-enclosed seas like the Red Sea. Also, arts. 74 (3) and 83 (3) may be invoked here with the option for states to enter into provisional arrangements when a boundary agreement has not yet been agreed upon (Colson and Smith 1993-2010, vol. V, p. 3468-3470). A median line with an extent of more than $300 \mathrm{~nm}$ in the middle of the Red Sea would appear to be equitable. But in all likelihood, and in view of rising metal prices, a massive border conflict between Sudan and Saudi Arabia is to be expected. A first sign of conflict is Saudi Arabia's declaration of straight baselines in the Red Sea ${ }^{17}$ to the effect that a median line would be moved westward at the expense of Sudan.

\subsection{Mining interests in outer continental shelf zones - the Arctic Ocean}

The worldwide problem of contested maritime borders is further complicated through the current process of delimitation of outer continental shelves. According to the criteria of art. 76, states may claim a continental shelf beyond the 200-nm limit, wherever the continental margin extends in geological terms beyond the 200-nm limit. If the geological criteria are met, the Commission on the Limitation of Continental Shelf (CLCS $)^{18}$ can evaluate the claim and recommend borderlines at an outer limit not exceeding $350 \mathrm{~nm}$ or-alternatively-100 miles from the 2,500 $\mathrm{m}$ isobath. ${ }^{19}$ Until September 2011, the CLCS has received 57 applications from 45 states. In total, some 74 states have either lodged submissions or indicated their intent to do so, covering an estimated area of more than 23 million $\mathrm{km}^{2}$ (Colson and Smith 1993-2010, vol. VI, 2010, pp. 4141). Some of the most spectacular claims refer to

\footnotetext{
${ }^{15}$ Saudi-Sudanese Agreement of 1974 relating to the joint exploration of natural resources of the seabed and the sub-soil of the Red Sea.

${ }^{16}$ For an update of the situation, see Bertram et al. (2011).

${ }^{17}$ Law of the Sea Bulletin no. 72, New York, 2010, p. 81-86 with text of declaration and map.

18 The CLCS, established in New York in 1996, is one of the three permanent institutions of UNCLOS; see art. 76 (8) and Annex II.

19 The first 11 recommendations of the CLCS are available at www.un.org/Depts/los/index.htm.
} 
large ocean spaces in the Arctic (Russian claim of 2001 to include the North Pole) and in the Indian Ocean (French/Australian claims on the Kerguelen ridge). The Pacific Ocean deserves special attention because a cascade of outer continental shelf claims has been tabled by, e.g., New Zealand, the Solomon Islands, Papua New Guinea, Federal States of Micronesia, Fuji, Vanuatu and the Cook Islands, Kiribati, and Tuvalu. As a consequence, new boundary conflicts arise beyond $200 \mathrm{~nm}$ not only among neighboring states but also in relationship to the International Seabed Authority.

The Arctic Ocean is currently at the center of the outer continental shelf discussion. In fact, the Arctic is becoming the test bench for international politics. It is an ocean where oil and gas, minerals, fisheries, sea lanes, military interests, and governance over ocean spaces meet in conflict among the five "frontline" states (USA, Canada, Denmark/Greenland, Norway, and Russia) while other neighboring entities like Iceland, the EU, Japan, and China express their Arctic interests as well.

All these happen at the same time when Arctic temperatures are rising twice as fast as in the rest of the world ${ }^{20}$ and climate change becomes incalculable. The warming temperatures break up polar ice, raise sea levels, erode coastlines at a remarkable speed, ${ }^{21}$ and potentially cause international conflicts as the Arctic becomes accessible at least during the summer. The USA, unlike the other Arctic states, is falling behind in this contest with little or no icebreaking and naval capacities in the region. Moreover, since the USA has not ratified the Law of the Sea Convention, it is neither in a position to claim outer continental shelf areas nor has a say in the International Seabed Authority ISA which will be responsible for deep-sea mining in central parts of the Arctic. Denmark, on the other hand, is working on its "Arctic strategy" with an anticipated claim of outer continental shelves north of Greenland to include the pole, which will be formally presented to the CLCS before 2014 .

\subsection{Summary}

With a view on the maritime dimension of conflicts over (seabed) resources, a few typical circumstances (Mildner et al. 2011) have to be met before the breakout of a real political/military confrontation at sea:

1. The existence of valuable marine resources in disputed waters, e. g., in an EEZ which is claimed by two or more states

2. A drastic general increase of commodity prices and a lack of alternative supplies

3. A threat of a monopoly and/or a declared or undeclared embargo

4. Public/political awareness of the conflict (and its maritime dimensions)

5. Failure of international governance instruments for dispute settlement (WTO, G20, international courts, arbitration)

The legal instruments to solve this type of maritime conflict are basically in place in the form of dispute settlement procedures or through bilateral agreement. A large

\footnotetext{
${ }^{20}$ The temperature of Atlantic currents inflow into the Arctic (Fram Strait) is $2^{\circ}$ higher than usual; www. ifm-geomar.de.

${ }^{21}$ Two thirds of Arctic coastlines consist of frozen soft substrate (permafrost) reacting to climate change with erosion, in some cases at a speed of half a meter to $8 \mathrm{~m} /$ year; see "State of the Arctic Coast 2010Scientific Review and Outlook of April 2011," www.arcticcoasts.org.
} 
number of notorious conflicts have been settled by means of border agreements, ${ }^{22}$ decisions of international courts or - in rare cases - also by the establishment of joint development zones where two states closely cooperate. With a bit of goodwill on behalf of governments, there is a variety of solutions available while UNCLOS offers a set of criteria for the delimitation between states with opposite or adjacent coasts for territorial seas, exclusive economic zones, and continental shelves. ${ }^{23}$ If neighboring states cannot solve their borderline conflicts by agreement, art. 287 of UNCLOS offers a choice of procedure for binding decisions of different international tribunals, like the LOS Tribunal in Hamburg and the International Court of Justice in The Hague or ad hoc arbitral tribunals (Kwiatkowska 2010; Noussia 2010). Even though the law to mediate border conflicts exists, we see a growing number of serious disputes. In many cases, the political will of states to resort to existing procedures is missing because valuable resources, access rights to ports, and sea routes or protracted hostility between neighboring states are in the way of a peaceful solution. In such cases, only good governance and wise politicians can help to avoid a military confrontation between states.

These requirements may be typical for the emergence of "classical" international conflicts involving two or more opposing states over borderlines or fishing or transit rights. But there are other developments where the underlying causes arise from intra-state conflicts or civil wars that may trigger a real international conflict as well:

1. The piracy off Somalia, based originally on the local problems of a failing state, involves the international community when criminals operate in international waters.

2. The revolution in Libya provides an example of a state where the rich revenues of its oil and gas production end up with a corrupt dictator leaving the population starving and without human and political rights.

3. Sierra Leone with its "blood diamonds" and Congo with its rare earths finance endless civil wars which destabilize the whole region and sooner or later trigger international conflicts.

There is every reason to believe that the number of such internal conflicts which have the tendency to generate international conflicts is on the rise as well. If the community of states decides to intervene in such cases for humanitarian reasons, they are confronted with complicated questions of international law. First and foremost, a legal basis for intervention is needed before the wide spectrum of reactions can be implemented, ranging from humanitarian aid, evacuation, risky helicopter missions, and no-fly zones down to military intervention with ground forces. Also, shipping interdiction will only be justified if a permissive rule of international law or permission from the flag State or the coastal State is given. Resolutions by the UN Security Council will help to provide a legal basis for intervention as will be discussed in Section 5 below.

\section{Natural disasters and climate change}

To complete the picture of "new" risks at sea which have a massive legal (and territorial) impact, a brief hint at conflicts related to climate change has to be added

${ }_{22}$ Documented in the six volumes of Colson and Smith (1993-2010).
Arts. 15, 74, and 83. 
here. Earthquakes, tsunamis, Katrina-magnitude storms, and floods are among the extreme weather events that hit modern societies unexpectedly "out of the blue." With a view to climate change, we may expect more serious disasters to happen. Governments, local administrations, and society at large are normally ill prepared in their civil defense efforts. They react too late, feel the fragility of human life, and complain over non-existent provisions. A new and secondary role in disaster reaction emerges for all coastal states. The military and police forces are among the services that can intervene at short notice with manpower, vessels, helicopters, air transport, heavy equipment, and communications. For the lawyer, the new topic is "disasters and law" with little or no legal framework so far.

As regards the rising sea level, massive legal consequences may be anticipated when states lose their territory, totally or in part. The loss of habitat undermines the living conditions of low-lying coastlines, estuaries, and small islands. If the coastline moves, the baselines have to follow. Considerable unrest can be expected when existing maritime boundaries must be shifted due to the loss of territory (Houghton et al. 2010). Small island states may disappear completely. As a consequence, maritime zones such as the territorial seas and EEZs could be significantly altered or even reversed into high seas. What happens when a State disappears? Where can the homeless inhabitants be evacuated and how to compensate them? Here, the law of succession of states is confronted with the law of the sea, with unknown solutions. At least in the case of shifting maritime borders among neighboring states, conflicts can be mitigated by using a range of existing tools such as joint development zones or renegotiating borders in the sea.

Due to sea level rise and more frequent violent storms, all coastal states will also see damaging impacts such as reduced beaches and stress on port infrastructure and dikes. In these cases where the underlying reason is not an international conflict but climate change as a global phenomenon, there is little or no law available. New law is needed, and states have the choice between new domestic and regional (multilateral) law or universal new law-preferably through the United Nations. Solidarity and responsibility of UN member states will be demanded-a challenge and chance for the UN.

It is worthwhile mentioning that in the rebellion in Libya of 2011, as in earlier domestic conflicts, the United Nations Security Council manifestly expressed the responsibility of the Libyan government for the protection of the civilian population. ${ }^{24}$ The concept of responsibility to protect the population as a justification for humanitarian intervention is a new and still contested argument ${ }^{25}$ which may be invoked in the future more frequently. If this humanitarian argument is raised in the case of evolving political threats to security posed inside failing states, it will be more than justified in the case of natural disasters and other catastrophes as well. Resolutions of the Security Council taken by unanimity allow for military/naval intervention by outside powers. This idea will be taken up at the end of this paper after looking into another risky area-that of communication.

\footnotetext{
${ }^{24}$ UN S.C. Res. 1973 (2011) of 17 March 2011; see text of preamble reiterating the responsibility of state authorities to protect their civilian population and using this argument to implement a no-fly zone, an arms embargo, and freezing of assets for Libya.

${ }^{25}$ UN S.C. Res. 1674 (2006) of 28 April 2006 and UN General Assembly Res. 60/1 (2005), para. 138-140.
} 


\section{Security of communication-sea lanes and cables}

\subsection{Changing sea lanes}

In the rapidly changing globalized world of today, $90 \%$ of international transport is sea borne, while old risks and new risks coincide. Major shipping and pollution accidents will continue, though at a reduced rate, because the maritime safety legislation of IMO is being implemented and controlled with greater effectiveness by flag states and port states. Thus, maritime safety seems to be well on the way while maritime security is on the focus now. Piracy and terrorism are contemporary challenges, and in some instances, we see piracy and terror acting jointly. Straits, canals, and other geographic chokepoints as well as logistic hubs like big ports offer a possible target for terrorists. ${ }^{26}$ With chaos erupting in the Arab world, and possibly also in other regions, states and navies have to be prepared for the protection of maritime transport and for maritime rescue operations to evacuate their citizens and other civilian refugees (non-combatant evacuation). To meet such challenges, military and civilian vessels and aircraft will be needed at short notice and in close interaction.

At the same time, we must realize that traditional shipping lanes and transport patterns are changing. Traditionally, the routes across the North Atlantic, the North Pacific, and the Indian Ocean linking the industrial centers of East Asia, Europe, and North America were dominant. This is changing due to several developments:

- The rise of Brazil, the Russian Federation, India, China (the "BRIC" states) and South Africa and certain Emirates leads to new cargo flows.

- Much more cargo will be moved around the equator, through the expanded Panama Canal (Mulligan and Lombardo 2011) and in Southern seas, where port infrastructure and canal infrastructure are booming.

- More raw material transports from Latin America, South Africa, and Australia will add to this scenario.

- In addition to traditional oil transport patterns, a massive increase in LNG transports is anticipated including newly built LNG terminals offshore and on land.

- The polar sea routes around the Arctic and in Antarctica (cruise ships) will be used more frequently.

- Regional seas like the Baltic and the Mediterranean will see more traffic ${ }^{27}$ as the concept from road to sea is implemented and Russian oil exports boom.

- The cruise industry increased by 50\% between 2006 and 2010 and continues to do so. More than 500,000 passengers and crew are embarked on cruise ships every day.

The volume of trade and the number of passengers will increase as the economy recovers and Asian development continues to progress. If, in the future, air transport

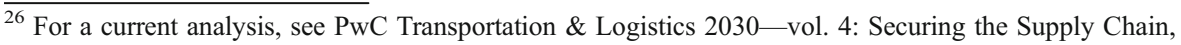
2011, p. 16-20; www.pwc.com/t12030.

${ }^{27}$ There are some 230 ferry lines in European waters. See Fähren, Routen, Reedereien, Verband der Fährschifffahrt und Fährtouristik e. V., Hamburg 2011. For the maritime traffic in the Mediterranean, an increase of $18 \%$ is predicted for the decade 2010/2020. In the Baltic Sea, traditional feeder ships are increasingly replaced by large container ships.
} 
comes under fire due to its negative influence on the climate, sea transport may get an additional boost. As new trade routes and opportunities emerge, the cumulative effect of these developments is that security at sea must be guaranteed in new regionsoften with new hotspots and far away from the traditional (Northern) centers of gravity. Uncertain times lie ahead.

\subsection{Installations and cables}

Canals, tunnels, and bridges over straits, submarine pipelines for oil and gas, ${ }^{28}$ as well as cables serve communication and transport purposes in the widest sense. These types of marine infrastructure can easily suffer from natural disasters or become targets of terrorism. ${ }^{29}$ It may be recalled that millions of telephone, telex, TV, and data links are made across the world at every moment. They may travel on radio waves or via satellites, but the majority are transmitted by submarine cables, ${ }^{30}$ which form a network over the world's seabeds. Cables are special because they provide the privacy and security that radio and satellite lack. They are reliable and long lasting and have an excellent capacity and transmission quality. Cables are vitally important to the global economy, to national security, and to the safety of life. ${ }^{31}$ The modern version of these arteries of data flow is fiber-optic cables running through oceans, straits, and across land bridges. For example, the bulk of data flow between Europe and the Far East goes by fiber-optic cables that run from the Mediterranean through Egyptian territory into the Red Sea and the Gulf of Aden. A high concentration of cables can be found in the South China Sea, Red Sea, and Mediterranean Sea. Likewise, a growing number of subsea cables for the transport of electricity are or under construction or in the planning process. Building up redundencies or back-up solutions will add to the picture, create additional intrusion on the environment, and offer a target for terrorists. Thus, the protection of "critical" marine infrastructure is part of the agenda.

Regarding the protection of cables and pipelines, the law of the sea is incomplete. On the one hand, all states enjoy the right to lay, to maintain, and to repair cables and pipelines in the EEZ, on continental shelves, and in archipelagic waters of a foreign State $^{32}$ and in high-sea areas. ${ }^{33}$ This would not include the right to actively protect these submarine installations by military means, except in the case of self-defense against an imminent attack. Apart from this exception, all policing rights of protection inside zones of maritime jurisdiction rest with the coastal states which have to adopt national laws to protect cables. In the case of damage to cables and pipelines, the normal remedy would be liability and compensation by those who are responsible for the damage.

\footnotetext{
${ }^{28}$ Pipelines for the transport of liquid carbon dioxide for the purpose of permanent storage under the seabed will become a future use.

${ }^{29}$ UN General Assembly Res. "Oceans and the Law of the Sea," A/65/37 of 17 March 2011, p. 3-4 and no. 121.

${ }^{30}$ More than $90 \%$ of cyber traffic is by cables.

${ }^{31}$ For further details, see Kingfisher Cable Awareness Chart, North Sea Central, December 2010.

${ }^{32}$ Arts. 58 (1), 79, and 51 (1).

${ }^{33}$ Art. 87 (1 c) and (2).
} 


\section{A way ahead: resolutions under chapter VII of the UN Charter}

As a rule, national (domestic) law allows for intervention and prosecution against all intruders and lawbreakers, irrespective of their nationality only in national waters. In international waters, the flag state principle of art. 92 prevails, and an interdiction or intervention is only legal against nationals of that state or against ships under that flag. ${ }^{34}$ Additionally, however, UNCLOS declares a few offenses ${ }^{35}$ like piracy, trafficking in drugs, and slaves on the high seas as internationally outlawed offenses which may be controlled by warships of all nations. Warships may board foreign vessels, arrest persons, or cooperate in the suppression of these offenses as an option, but do not have a duty to do so. Thus, the fight against piracy is a voluntary (discretionary) task while terrorism is not even mentioned in UNCLOS. These are among the main gaps in the law of the sea.

Here, the growing role of the Security Council as a "world legislator" has to be noted (Talmon 2005; Keyuan 2011) against the traditional perception that (only) states are the legislators in the international legal system. In fact, the UN Security Council stepped in on various occasions and expanded the law through unanimous resolutions under chapter VII of the UN Charter ${ }^{36}$ in order to maintain and protect international peace and security. The Security Council enjoys a wide discretion when to decide that a conflict, be it an international or even an intra-state conflict, constitutes a threat to international peace and security. Decisions of the Council which require unanimity may go as far as military intervention and are binding upon all UN member states (Wolfrum 1991, p. 764-771; Keyuan 2011, p. 236).

\subsection{Anti-piracy resolutions}

Concerning piracy off Somalia, a series of Security Council resolutions ${ }^{37}$ opened up the ways and means to combat piracy "inside the territorial waters of Somalia," to use "all necessary means" and ultimately also to act "in Somalia," thus expanding the anti-piracy rules of UNCLOS considerably. Most of these resolutions also urge states to criminalize piracy under their domestic laws and to improve the procedures to bring pirates to justice by national courts and/or regional/international courts.

A similar series of resolutions refers to the fight against terrorism. In this case, the Security Council referred additionally to the concept of self-defense. And, in fact, self-defense can be a legal basis to respond to maritime violence in international waters. Among the fundamental rights of states, self-defense is enshrined in the Charter of the United Nations in chapter VII within the framework of actions with respect to threats to peace and acts of aggression. Art. 51 of the UN Charter reads:

Nothing in the present Charter shall impair the inherent right of individual and collective self-defence if an armed attack occurs against a Member of the United Nations, until the Security Council has taken measures necessary to maintain international peace and security.

\footnotetext{
${ }^{34}$ Flag state principle, art. 92.

${ }^{35}$ Arts. $98-111$.

${ }^{36}$ Arts. 39-51 UN Charter.

${ }^{37}$ UN S.C. Res. 1814 (2008), 1816 (2008), 1838 (2008), 1844 (2008), 1846 (2008), 1851 (2008), 1897 (2009), 1918 (2010), 1950 (2010), 1976 (2011)
} 
The Charter defines the right of self-defense in a restrictive way, and the International Court of Justice has refined the limits in more detail (Keyuan 2011, pp. 246). Art. 51 limits the right of self-defense to cases of an illegal armed attack as distinct from an ordinary breach of international law. In the first place, it has to be an armed attack that must be instant, imminent, and overwhelming, leaving no other choice of reaction. The attack must be a threat to international peace and security. A threat of attack is not sufficient so that pre-emptive self-defense is illegal. ${ }^{38}$ The defensive countermeasures have to meet the test of proportionality to avoid excessive defense. The use of force has to be terminated as soon as the attack has ended. Finally, states acting in self-defense have to comply with the principles of humanitarian law. The right of defense is available only to a state which defends its rights against another aggressor who is representing a state as well. Thus, the normal case of self-defense will be a military attack countered by the military force of the defender. Finally, selfdefense at sea is only possible for warships and government ships.

In the case of modern security risks, such as piracy and terrorism, the aggressor is a non-state actor since pirates are largely "normal" criminals with the aim of opportunistic economic gain rather than political ends. Terrorists and insurgents may be politically motivated but normally are not the representatives of an existing State. Thus, the traditional concept of self-defense cannot be invoked directly by State authorities in their fight against non-traditional — or asymmetric — attacks or threats. On the other hand, pirates and terrorists often make use of military weapons so that the criterion of an "armed attack" is met. Moreover, the argument is raised that if a failing State is unable or unwilling to assert control over terrorists (and pirates) in its territory, a victim state of terrorist attacks would be permitted to act in self-defense (Wilmshurst 2006). It is this kind of "reasonable" arguments serving the basic interests of states that pave the way as the law develops.

\subsection{Anti-terror resolution 1373}

In the fight against terror, UN Security Resolution 1373 (2001) ${ }^{39}$ adopted by unanimity and thus binding upon all UN member states broke new ground and established steps and strategies to combat international terrorism by non-state actors. Most importantly, this resolution reaffirms that terrorism as such constitutes a threat to international peace and security with the consequence that the right of individual or collective self-defense is applicable. ${ }^{40}$ Under the terms of the text, the Council further imposes the duty of states to implement domestic anti-terror laws and regulations with regard to the prevention and suppression of terrorism in the domain of financing, prosecution and criminal jurisdiction, traffic in arms, border controls, exchange of information, laws of asylum seekers and refugees, and other areas of organized crime.

Therefore, warships and other government ships are allowed to act against terrorists on the basis of art. $51 \mathrm{UN}$ Charter because Res. 1373 brings terrorist acts in line

\footnotetext{
$\overline{38}$ The doctrine of pre-emptive action, although still controversial in international law, is generally rejected; see Grey (2007).

${ }^{39}$ UN S.C. Res 1373 (2001), adopted unanimously on 28 September 2001.

${ }^{40}$ See UN S.C. Res. 1368 (2001) and preamble and no. 5 of Res. 1373 (2001).
} 
with an armed attack of a hostile state, the only condition being that the attack by terrorists be the equivalent of an armed attack.

\subsection{WMD Resolution 1540}

A similar idea can be found in Resolution 1540 (2004), ${ }^{41}$ commonly referred to as the "WMD Resolution." This resolution requires all states to criminalize the proliferation of weapons of mass destruction (WMD), to enact strict export controls and to secure all sensitive materials within their borders.

It may be recalled that Res. 1540 had been triggered by the Proliferation Security Initiative (PSI) of the USA. As a response to the growing challenge posed by weapons of mass destruction, their delivery systems and related materials, the US Government started the PSI in 2002 and presented it publicly in May $2003 .{ }^{42}$ However, PSI is neither a legal instrument nor an international organization, but rather a process of voluntary government cooperation to raise security awareness and take steps to interdict the flow of such items at sea, in the air, or on land. More than 10 "core members" and some 50 participating states committed to this political process.

The idea of interdiction gained a legal quality when the Security Council incorporated it into Resolution 1540. Under no. 10, this text calls upon "all states" to take cooperative action to prevent illicit trafficking in WMD weapons, their means of delivery, and related materials. Again, this resolution is based on chapter VII. Its preamble recalls the right "to take appropriate and effective actions against any threat to international peace and security" and expresses concern over the risks of non-state actors and terrorists. Moreover, the text offers a definition of a non-state actor as an "individual or entity, not acting under the lawful authority of any State on conducting activities which come within the scope of this resolution". Resolution 1540 provides no new enforcement authority as it concentrates on the behavior of states. But, as a minimum, the wording of resolution 1540 is clearly hinting at the right of self-defense against WMD activities by non-state actors, thus expanding again the right of self-defense against non-state actors which originally only applies if an armed attack occurs by a state.

\subsection{New rules for boarding of suspected vessels}

An interesting by-product of these anti-terror initiatives is new bilateral agreements for boarding and inspecting suspected foreign-flag vessels. Since 2004, the USA has concluded bilateral ship-boarding agreements with 11 states, ${ }^{43}$ representing far more than $50 \%$ share of world tonnage. These agreements are modeled after similar agreements that exist in the counter-narcotic area. ${ }^{44}$ Such agreements typically allow

\footnotetext{
${ }^{41}$ UN S.C. Res. 1540 (2004) adopted by the Security Council at its 4956th meeting on 28 April 2004 and extended by Res. 1673 (2006) for another 2 years; text: 43 ILM 1237 (2004).

42 Congressional Report Service, CRS Report for Congress: Sharon Squassoni, Proliferation Security Initiative PSI, updated 14 September 2006.

${ }^{43}$ Antigua and Barbuda, Bahamas, Belize, Croatia, Cyprus, Liberia, Malta, Marshall Islands, Mongolia, Panama, St. Vincent, and the Grenadines; see US State Dept. www.state.gov/t/isn/c27733.htm, visited 08 Oct. 2011.

${ }^{44}$ Agreement Concerning Co-operation in Suppressing Illicit Maritime and Air Trafficking in Narcotic Drugs...in the Caribbean Area. See http://www.state.gov/s/1/2005/87198.htm.
} 
for states parties $2 \mathrm{~h}$ to deny US personnel the right to board a ship. But again, there are gaps. The agreements may allow for boarding, but not necessarily for cargo seizure. Cargo can only be seized in port, if the laws of the port State are violated. It was probably under one of these boarding agreements that the US destroyer McCampbell intercepted the $M / V$ Light (under the flag of Belize) on 26 May 2011 suspected of carrying missiles or other weapons from North Korea to Myanmar and made it turn back. ${ }^{45}$

A multilateral convention with innovative boarding rights is the Protocol of 2005 of the Convention for the Suppression of Unlawful Acts Against the Safety of Maritime Navigation, better known as the SUA Protocol of $2005 .^{46}$ The negotiating forum was not the UN Security Council but IMO, the competent international organization, as it is named throughout the Law of the Sea Convention. The new protocol entered into force on July 28, 2010, after being ratified by a minimum of 12 states. The original SUA Convention of 1985, in force for some 140 states now, was negotiated in response to the hijacking of the Achille Lauro and deals with the criminal prosecution of offenders. The 2005 Protocol, pushed by the US in the wake of $9 / 11$, establishes a variety of new offenses of violence at sea, mostly related but not restricted to unlawful carriage, use, or operation of WMD materials against vessels and platforms.

The new SUA Protocol 2005 also covers cooperation and procedures for boarding vessels under a regime of consensual boarding. The details are to be found in the 15 paragraphs of art. 8bis. If a warship of a requesting state encounters a suspect vessel under the flag of another state party outside any territorial sea, i.e., in an EEZ or on the high seas, it may request the flag state's authorization to board and take "appropriate measures." In that case, the flag state shall either authorize or deny boarding. If the flag state does not grant the request, the requesting state must not board. However, under paragraph 5 (d) and (e) of art. 8bis, a flag state may under two different modalities waive its right to grant consent by a formal notification to the Secretary General of IMO in the interest of facilitating boarding. The first option is an "automatic consent" if the ship's nationality is not confirmed within $4 \mathrm{~h}$. The second option is a blanket pre-authorization ${ }^{47}$ without the $4-\mathrm{h}$ rule. These innovative boarding rules try to reconcile the flag state rights and the need to allow for expeditious control rights. Furthermore, these agreements apply only to merchant ships, not to government transports. Thus, WMD transport by "rogue states" onboard government vessels cannot be intercepted.

However, these procedures only apply as between states parties to SUA 2005. Moreover, ratifying states have formally to declare their consent to the simplified boarding regime. As of 31 March 2011, some 20 states $^{48}$ have acceded, representing $30 \%$ of the world fleet. With the exception of Panama, Marshall Islands, and St. Kitts, many major maritime powers (USA, Britain, Russia, Germany, France) and countries with large fleets (Japan, China, Greece, Norway) still abstain. This lack of interest on

\footnotetext{
$\overline{{ }^{45} \text { New York Times of } 12 \text { June } 2011 .}$

${ }^{46}$ IMO Document LEG/Conf.15/21 and 22; text also under www.imo.org/conventions/

${ }^{47}$ IMO Document LEG/Conf.15/21, p. 181.

${ }^{48}$ Algeria, Austria, Bulgaria, Dominican Republic, Estonia, Fiji, Latvia, Liechtenstein, Marshall Islands, Netherlands, Panama, St. Kitts, St. Vincent, Serbia, Spain, Switzerland, Turkey, Vanuatu, representing together $30 \%$ of world tonnage.
} 
behalf of major seafaring nations, naval powers, and EU Member States is surprising given the wordy statements of their politicians advocating the war on global terrorism.

\subsection{Summary}

Finally, the question remains how to resolve existing legislative gaps and ambiguities in the field of safeguarding, safety, and security at sea. With a view to the weaknesses of the piracy regime of UNCLOS, it has been discussed that the SUA regime could offer a complementary role in that it covers all acts of violence at sea irrespective of maritime borders (Mejia and Mukherjee 2004). The UN Security Council has taken up this idea in most of its anti-piracy resolutions ${ }^{49}$ and constantly reminds the states parties to the SUA 1988 Convention "to fully implement their obligations ... for the successful prosecution of persons suspected of piracy and armed robbery at sea off the coast of Somalia." 50 Thus, for the first time, a clear statement was made in favor of the applicability of SUA 1988/2005 to criminal acts of piracy. Consequently, the broad concept of maritime violence, as used in both SUA versions, should be taken as a starting point for future legislation in all areas of security because this wording is a fitting generic term to cover all modern manifestations of violence ranging from terror, piracy, trafficking in arms and drugs, down to "normal" criminal offenses (Mejia and Mukherjee 2006, p. 184; Jenisch 2009, p. 133).

A first step, however, is ratification and full implementation of SUA 2005 by all major seafaring states. In a second step, the legislative organs of IMO, the "competent international organisation" for the safety (and security?), could further refine and broaden the SUA rules to cover all types of maritime violence. A second best solution is bilateral "constabulary" agreements between flag states that allow for inspection, interdiction, and seizure.

Apart from IMO, the UN Security Council will play a central role in the legalpolitical fight against maritime violence. The Security Council as a "world legislator" has expanded its role and may well produce more new rules of intervention. ${ }^{51}$ The combination of the two concepts in chapter VII, namely that of self-defense - art. 51and that of defense of peace and security, including the protection of innocent civilians under the responsibility to protect formula, may well serve as a basis for new legislation. The advantage of UN and IMO legislation is its universal character as compared to bilateral or regional agreements which are only binding upon the states that have ratified or acceded. The first priority clearly is a universal security framework at sea and not a patchwork regime. But, of course, there is always room for a combination of UN Security Resolutions and bilateral or regional initiatives such as boarding and inspection agreements (Ruppel 2008), or regional anti-piracy cooperation activities. After all, pragmatism is one of the elements of the law of the sea.

\footnotetext{
${ }^{49}$ See above Fn. 50.

${ }^{50}$ UN General Assembly Res. "Oceans and the Law of the Sea," A/65/37 of 17 March 2011, no. 98.

${ }^{51}$ UN S.C. Res. 1973 (2011) on Libya.
} 


\section{References}

Bertram C et al. (March 2011) Metalliferous sediments in the Atlantis II Deep. Kiel Institute for the World Economy, Kiel working papers no. 1688, p. 30

Bruns S (2011) Iranischer Marinebesuch in Syrien. MarineForum, no. 6, p. 11-12

Colson DA, Smith RW (eds) (1993-2011) International maritime boundaries, vol. I-VI. Martinus Nijhoff Publishers, Leiden. 4779 pp (Volumes I-III have been edited by Charney, Jonathan I./Alexander, Lewis M., Vol. IV by Charney/Smith), Martinus Nijhoff Publishers

Crook JR (ed) (2010) Secretary of state urges multilateral approach to China's South China Sea claims. AJIL 104(4):664-666

Grey C (2007) A crisis of legitimacy for the UN Collective Security System? 56 ICLQ, pp. 157-170

Houghton KJ et al (2010) Maritime boundaries in a rising sea. Nat Geosci 3:813-816

Jenisch U (2009) Piracy, navies and the law of the sea: the case of Somalia. WMU J Marit Aff 8:133

Kato Y et al (2011) Deep-sea mud in the Pacific Ocean as a potential resource for rare-earth elements. Nature Geoscience, p. 373-382

Keyuan Z (2011) Maritime enforcement of UN Security Council resolutions: use of force and coercive measures. IJMCL 26:235-261

Kwiatkowska B (2010) Decisions of the world court relevant to the UN Convention on the Law of the Sea. A reference guide, 2nd ed. Martinus Nijhoff, p. 346

Mejia M, Mukherjee PK (2004) Selected issues of the law and ergonomics in maritime security. J Int Marit Law 10:316-326, Refer to p. 321

Mejia M, Mukherjee PK (2006) The SUA Convention 2005: a critical evaluation of its effectiveness in suppressing maritime criminal acts. J Int Marit Law 12:170-191

Mildner SA et al (eds), Konfliktrisiko Rohstoffe? Herausforderungen und Chancen im Umgang mit knappen Ressourcen. Berlin, SWP Studie 2011/S of 5 February 2011, 228 p; English version: Resource scarcity — a global security threat? SWP Research Paper RP 2, March 2011, p. 30

Mulligan RF, Lombardo GA (2011) Panama Canal expansion: alleviating global climate change. WMU J Marit Aff 10(1):97-116

Noussia K (2010) On international arbitrations for the settlement of boundary maritime delimitation disputes from joint development agreements for the exploitation of offshore natural resources. IJMCL 25:63-80

Prescott V, Schofield C (2005) The maritime political boundaries of the world. Martinus Nijhoff Publishers, Leiden

Ruppel C (2008) Die Proliferation Security Intiative PSI-Eine Analyse und die Perspektiven. Mar Forum 83(12):6-7

Talmon S (2005) The Security Council as world legislature. AJIL 99:175

Wilmshurst E (2006) The Chatham House Principles of International Law on the use of force in selfdefence. ICLQ 55:963-972, refer to 970

Wolfrum R (ed) (1991) Handbuch Vereinte Nationen. München, p. 764-771 